\title{
TEMPORAL VARIATION IN THE RED GROUPER, EPINEPHELUS MORIO, DEMOGRAPHIC STRUCTURE FROM SOUTHERN GULF OF MEXICO
}

\author{
Doralice Caballero-Arango $^{1 *}$, Thierry Brule ${ }^{1}$, Jorge L. Montero-Muñoz ${ }^{1} \&$ Teresa Colás-Marrufo ${ }^{1}$
}

\begin{abstract}
Changes in the demographic structure of red grouper Epinephelus morio from the southern part of the Gulf of Mexico, were evaluated during periods when total catches, CPUE and annual yields of the specie decreased. Fishery-dependent samples $(\mathrm{n}=1887)$ were obtained between August 1989 and February 2004 from the Campeche Bank, and size-frequency distributions by sex, sex ratios and sizes of sexual maturation and sex change were compared between three periods: $\mathrm{P} 1_{1989-1992}(\mathrm{n}=886) ; \mathrm{P} 2_{1996-1998}(\mathrm{n}=413)$; and $\mathrm{P}_{2}{ }_{2003-2004}(\mathrm{n}=588)$. The temporal stability of size-frequency distribution by sex, with males always being larger than females, and the sex ratios always biased towards females, were consistent with this species' type of sexuality. Size for females and males, as well as sizes at first sexual maturity and at sex reversal all decreased from the oldest period to the more recent one and could be a consequence of the fishing intensity applied to this stock. The reductions in size of females and males associated with a relatively stable sex ratio and the lack of any drastic decrease in the number of males can be explained by this species' reproductive ecology. Results are discussed regarding the capacity for reproductive resilience of red grouper in response to fishing pressure like that currently experienced by the Campeche Bank stock.
\end{abstract}

Keywords: Serranidae, Epinephelus morio, demographic structure, fishing pressure, Southern Gulf of Mexico.

\section{RESUMEN}

Los cambios en la estructura demográfica del mero rojo Epinephelus morio en el sureste del Golfo de México fueron evaluados para períodos durante los cuales se observaron una disminución en las capturas totales, la CPUE y el rendimiento anual de la especie. Las muestras $(n=1887)$ fueron obtenidas a partir de las capturas comerciales realizadas entre agosto de 1989 y febrero del 2004 y las distribuciones de frecuencia de talla por sexos, la proporción por sexos, las tallas de primera madurez sexual y de inversión sexual, fueron comparadas entre tres períodos: $\mathrm{P} 1_{1989-1992}(\mathrm{n}=886)$; $\mathrm{P} 2_{1996-1998}(\mathrm{n}=413)$ y $\mathrm{P} 3_{2003-2004}(\mathrm{n}=588)$. La estabilidad temporal de las distribuciones de frecuencia de talla por sexos con los machos siempre de tamaño superior al de las hembras, y los valores de proporción sexual siempre sesgados a favor de las hembras fueron congruentes con el tipo de sexualidad presentada por la especie. La disminución del tamaño de las hembras y de los machos, así como de las tallas de primera madurez sexual y de inversión sexual de la especie entre el período de estudio más lejano hasta el más reciente, podrían ser una consecuencia de la intensidad pesquera ejercida sobre este stock. Las disminuciones de talla de las hembras y de los machos, asociadas a la relativa estabilidad de la proporción sexual y a la ausencia de una reducción drástica de la proporción del macho, pueden ser explicadas por la ecología reproductiva de la especie. Los resultados obtenidos son discutidos en relación con la capacidad de resiliencia reproductiva del mero rojo a la presión por pesca sufrida actualmente por el stock del Banco de Campeche.

Palabras claves: Serranidae, Epinephelus morio, estructura demográfica, presión pesquera, sureste del Golfo de México.

1 Departamento de Recursos del Mar, CINVESTAV-IPN Unidad Mérida, Antigua Carretera a Progreso Km. 6, A.P. 73 Cordemex, C.P. 97310 Mérida, Yucatán, México. doralice@mda.cinvestav.mx*.

Recibido 8-II-2010

Aceptado 24-VI-2010

DOI: http://dx.doi.org/10.15359/revmar.2.3 


\section{INTRODUCTION}

Reproductive ecology research providing data on the mechanisms and potential for population renewal are particularly vital for determining the long-term demographic effects of fishing on an exploited stock, and consequent implementation and fine-tuning of fisheries organization strategies (Vincent \& Sadovy, 1998). The reproductive biology of reef fish species has received limited attention compared to other aspects of their natural history. From a fisheries point of view, there is an urgent need to better evaluate the reproductive potential of reef fish populations, particularly for commercial species (Sadovy, 1996).

Groupers constitute an important ecological and economic component of the reef fish communities in the Gulf of Mexico (Bannerot et al. 1987). Due to their biology, these species can be very sensitive to intensive fishing. They are hermaphroditic with slow growth, late sexual maturity, long lifespan, low natural mortality rates and highly asymptotic sizes (Coleman et al. 1999; Coleman et al. 2000; Levin \& Grimes, 2002; Alonzo \& Mangel, 2004). A number of grouper species also form spawning aggregations, making them even more vulnerable to fishing (Ralston, 1987). According to Morris et al. (2000) of the 18 grouper species commercially exploited in the Gulf of Mexico, 13 are currently considered to be threatened.

Intensive fishing of groupers leads to decreases in catches, catch per unit effort (CPUE) and average size and weight of the organisms caught. It also produces reductions in the size of spawning aggregations, a sex ratio progressively more biased towards females and a decrease in size at first sexual maturity in females (Vincent \& Sadovy, 1998). However, the response of each grouper species to intensive fishing pressure is directly related to its reproductive strategy, which varies between species. For instance, species that form spawning aggregations, such as gag, Mycteroperca microlepis (Goode \& Bean, 1880), and scamp, Mycteroperca phenax (Jordan \& Swain, 1885) would be more affected by fishing than species that do not aggregate to spawn, such as red grouper, Epinephelus morio (Valenciennes, 1828), graysby, Cephalopholis cruentata (Lacepède, 1802), and coney, Cephalopholis fulva (Linnaeus, 1758) (Coleman et al. 1996; Vincent \& Sadovy, 1998; Levin $\&$ Grimes, 2002).

To date, the red grouper is the most heavily exploited grouper species in the southern Gulf of Mexico and especially on the continental shelf of the Yucatan Peninsula known as the Campeche Bank. Notwithstanding, over a 12-year period red grouper catches from Campeche Bank have decreased 47\%: from $13933 \mathrm{t}$ in 1991 to $6475 \mathrm{t}$ in 2003. In addition, CPUE (kg/ fishing day) decreased by $60 \%$ between 1980 (2400-2900 kg/fishing day) and 2002 (1150 kg/fishing day) (SAGARPA, 2005; 2006). Recent studies on the condition of this stock in the waters of the Yucatan Peninsula demonstrated that this fishery has reached a point of overexploitation. Bioeconomic yield-mortality models, fitted to the red grouper from Campeche Bank for the period 1980-1998, indicated that this species was overexploited (Burgos \& Defeo, 2004). Furthermore, a marked long-term decrease of annual yields of red grouper and a significant linear increase in total mortality of the species observed from 1980 to 2000, had been also viewed as a signal of stock overexplotation by Burgos \& Defeo (2004). Finally, according to Giménez-Hurtado et al. (2005) the 
Campeche Bank red grouper spawning stock size had decreased by $25 \%$ between 1986 and 2000, which could produce recruitment overfishing.

In response to the eventual impact of fishing on the reproductive potential of red grouper, the study aim was to evaluate changes in the demography of this species due to fishing pressure, by analyzing variations in size frequency distribution by sex, median size by sex distribution, sex ratio, median size at sexual maturity and median size at sex reversal for the Campeche Bank stock between 1989 and 2004 .

\section{MATERIALS AND METHODS}

Red grouper individuals $(\mathrm{n}=1887$ ) were collected from commercial catches by the Mexican fishing fleet on Campeche Bank $\left(20-23{ }^{\circ} \mathrm{N}, 86-92^{\circ} \mathrm{W}\right)$. Catches were made between August 1989 and February 2004 using bottom longlines on hard rocky or bedrock bottoms, and at depths ranging from 18 to $210 \mathrm{~m}$. Three sample periods were defined based on catch dates: $\mathrm{P} 1_{1989-1992}$ (June 1989-April 1992, 23 months, $\mathrm{n}=886$ ); $\mathrm{P} 2_{1996-1998}$ (April 1996-January 1998, 15 months, n = 413); and P3 ${ }_{2003-2004}$ (February-March 2003, 1 month, $\mathrm{n}=255$; and January-February 2004, 1 month, $n=333$ ). Each of these three periods includes catches from January to March, the peak reproductive period for red grouper in this region (Brulé et al. 1999). Specimens were analyzed in the laboratory for the ones collected during P1 or directly aboard fishery boats for these collected during P2 and P3. Fork length (FL) was measured to the nearest $\mathrm{mm}$ for each specimen and a fragment of its gonads preserved in Bouin liquid.
The gonad fragments were placed in Paraplast, sectioned (6 $\mu \mathrm{m}$ thickness) with a microtome and stained with Masson trichrome (Gabe, 1968). Organism sex (i.e. female, male or sex reversal) was determined microscopically from the histological sections, considering the criteria proposed by Smith (1959) and Sadovy and Shapiro (1987) for characterizing hermaphroditism in teleost fish. The degree of sexual development in females was determined using the five oogenesis cellular development stages defined by Wallace and Selman (1981). The reproductive condition was determined according to sexual maturity classes defined by Brulé et al. (1999) for female red grouper. Using the criteria of Shapiro et al. (1993) and Rhodes and Sadovy (2002), mature resting females were distinguished from immature females by the presence of abundant bundles of muscle in the ovarian lamellae and blood vessel-associated connective tissue.

Size frequency distributions by sex for each sampling period were determined and compared using the Kolmogorov-Smirnov non-parametric test (Sokal \& Rholf, 1997). First, a comparison was made of size frequency distributions between sex (male and female) for the same period, and second, a comparison was made between periods for each sex.

Median size for females and males was calculated for each period. This measurement of the central trend was used because it is less susceptible to effects from extreme values. Median values were compared with a Kruskal-Wallis non-parametric test (Sokal \& Rholf, 1997). Median size was also compared between sex for the same period and between periods for each sex group. 
Sex ratio was defined as the number of females per male (i.e. male: female =1: x) (Kartas \& Quignard, 1984) and calculated for each sampling period. The replicated G-test (Sokal \& Rholf, 1997) was used to determine if the sex ratio for each period differed from a balanced sex ratio $(1: 1)$.

All the analyzed specimens (size range = 32.0-89.0 cm FL) were obtained from catches landed by the commercial fleet, mainly including members of the adult fraction of the red grouper population caught in deep waters of the Campeche Bank. Consequently, median female size was calculated from a length range encompassing both immature and mature females, and was thus considered the size at which this species can reach first sexual maturity. Median sizes were calculated for each sampling period and compared using a Kruskal-Wallis non-parametric test (Sokal \& Rholf, 1997).

Following Shapiro (1984), median female size at which sex reversal could occur was estimated using the length range within which females and males occurred simultaneously. Median size at sex reversal was calculated for each period, and compared using a Kruskal-Wallis non-parametric test (Sokal \& Rholf, 1997). For all statistical analyses $\alpha=0.05$ (Infostat professional Version 1.1).

\section{RESULTS}

\section{Size frequency distribution and median sizes by sex}

Of the total number of the analyzed red grouper specimens, 75\% $(n=1418)$ were female, $24 \%(n=454)$ were male and $1 \%(n=15)$ were classified as in sex reversal. Independent of period and size interval, the size frequency distributions of females overlapped those of males (Fig. 1). Notwithstanding, size frequency distributions of females were always positively skewed, whilst those of males were generally negatively skewed, excepted during P2 ${ }_{1996-1998}$ when size distribution appeared positively skewed but with a more long right tail than in the case of females. Males were not observed in size classes less than $35 \mathrm{~cm}$ FL and females were not present in size classes more than $85 \mathrm{~cm}$ FL. Thus, for each period, the size frequency distributions of males were different from those of females (Kolmogorov-Smirnov; Table 1). Moreover, the median sizes in females (59.0 cm FL for $\mathrm{P}_{1989-1992}$; $53.5 \mathrm{~cm} \mathrm{FL}$ for $\mathrm{P} 2_{1996-1998}$ and $47.0 \mathrm{~cm} \mathrm{FL}$ for $\left.\mathrm{P} 3_{2003-2004}\right)$ were lower than in males $(66.6 \mathrm{~cm} \mathrm{FL}$ for $\mathrm{P} 1_{1989-1992}$; $58.0 \mathrm{~cm} \mathrm{FL}$ for P2 ${ }_{1996-1998}$ and $53.0 \mathrm{~cm} \mathrm{FL} \mathrm{for} \mathrm{P3_{2003-2004 }}$ ) for all periods (Kruskal-Wallis; Table 1). On the other hand, the size frequency distributions for females and males also differed between periods (Kolmogorov-Smirnov; Table 2) and median size for both sexes decreased significantly from the older to the most recent period (Kruskal-Wallis; Table 3 and Fig. 2).

\section{Sex ratio}

Sex-ratio results obtained for each studied period are presented in Table 4. Independently of the period, females were always more abundant than males in catches and consequently the calculated sex ratio (male: female) was biased towards females in all cases: 1:3.4 for $\mathrm{P} 1_{1989-1992} ; 1: 1.9$ for $\mathrm{P} 2_{1996-1998}$ and 1:4.1 for P3 ${ }_{2003-2004}$. These values clearly differed from a balanced (1:1) sex ratio ( $\mathrm{G}$ test; Table 4). The proportion of males observed during each period was: $22.7 \%$ in $\mathrm{P}_{1989-1992}, 34.3 \%$ in $\mathrm{P} 2_{1996-1998}$ and $19.4 \%$ in $\mathrm{P} 3_{2003-2004}$. No progressive or 
Table 1. Comparisons between size-frequency distributions and median sizes for female and male red grouper from Campeche Bank for each study period, between 1989 and 2004. $\mathrm{df}=$ degrees of freedom; $\mathrm{H}=$ Kruskal-Wallis test value; $\mathrm{KS}=$ Kolmogorov-Smirnov test value; $*=P<0.05 ; * *=P<0.01$

Cuadro 1. Comparación entre las distribuciones de frecuencia de tallas y medianas de machos y hembras del mero rojo del Banco de Campeche para cada período de estudio, entre 1989-2004. df = grados de libertad; $\mathrm{H}=$ valor de la prueba de Kruskal-Wallis; KS $=$ valor de la prueba de Kolmogorov-Smirnov; $*=P<0.05 ; * *=P<0.01$

\begin{tabular}{ccccccccc}
\hline Period & Sex & $\mathbf{n}$ & $\begin{array}{c}\text { Mode } \\
(\mathbf{F L} ; \mathbf{c m})\end{array}$ & $\begin{array}{c}\text { Size range } \\
(\mathbf{F L} \text { cm) }\end{array}$ & KS & $\begin{array}{c}\text { Median size } \\
(\mathbf{F L} \text { cm) }\end{array}$ & H & df \\
\hline $\mathrm{P} 1_{1989-1992}$ & Female & 676 & 55.0 & $40.0-85.0$ & $0.32^{*}$ & 59.0 & $73.1^{* *}$ & 1 \\
& Male & 199 & 75.0 & $40.0-90.0$ & & 66.6 & & \\
$\mathrm{P} 2_{1996-1998}$ & Female & 270 & 50.0 & $40.0-80.0$ & $0.25^{*}$ & 53.5 & $31.0^{* *}$ & 1 \\
& Male & 141 & 55.0 & $45.0-90.0$ & & 58.0 & & \\
$\mathrm{P}_{2003-2004}$ & Female & 472 & 45.0 & $30.0-80.0$ & $0.31^{*}$ & 47.0 & $31.7^{* *}$ & 1 \\
& Male & 114 & 65.0 & $35.0-80.0$ & & 53.0 & & \\
\hline
\end{tabular}

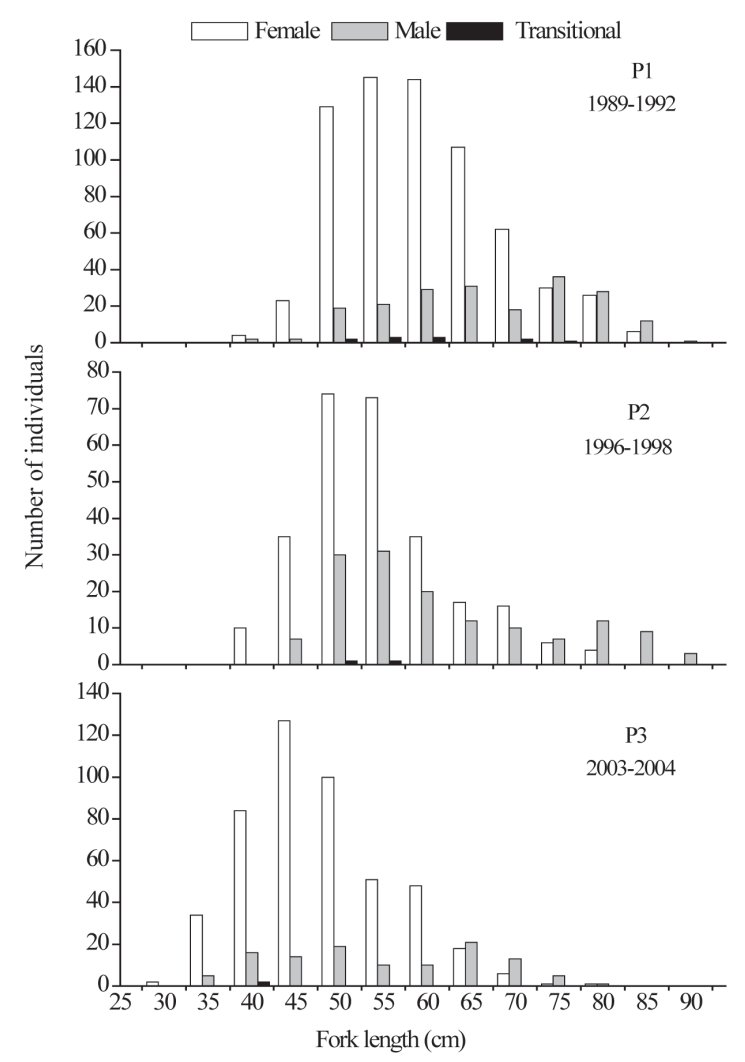

Fig. 1. Size frequency distributions for females, males and sex reversal red grouper from Campeche Bank collected during the three study periods, between 1989 and 2004

Fig. 1. Distribuciones de frecuencia de tallas para machos, hembras e individuos en inversión sexual del mero rojo del Banco de Campeche durante los tres períodos de estudio, entre 1989-2004 
Table 2. Comparisons of size frequency distributions for female and male red grouper from Campeche Bank between the three study periods, during 1989-2004. KS = Kolmogorov-Smirnov test value; $*=P<0.05$

Cuadro 2. Comparaciones de las distribuciones de frecuencia de tallas para hembras y machos del mero rojo del Banco de Campeche entre los tres períodos de estudio, durante 1989-2004. $\mathrm{KS}=$ valor de la prueba de Kolmogorov-Smirnov; * $=P<0.05$

\begin{tabular}{|c|c|c|c|c|c|}
\hline Sex & Period & $\mathbf{N}$ & $\begin{array}{c}\text { Mode } \\
\text { (FL; cm) }\end{array}$ & $\begin{array}{l}\text { Size range } \\
(\mathrm{FL} ; \mathrm{cm})\end{array}$ & KS \\
\hline \multirow{3}{*}{ Female } & $\begin{array}{l}\mathrm{P} 1_{1989-1992} \\
\mathrm{P} 2_{1996-1998}\end{array}$ & $\begin{array}{l}676 \\
270\end{array}$ & $\begin{array}{l}55.0 \\
50.0\end{array}$ & $\begin{array}{l}40.0-85.0 \\
40.0-80.0\end{array}$ & $0.27 *$ \\
\hline & $\begin{array}{l}\mathrm{P} 1_{1989-1992} \\
\mathrm{P} 3_{2003-2004}\end{array}$ & $\begin{array}{l}676 \\
472\end{array}$ & $\begin{array}{l}55.0 \\
45.0\end{array}$ & $\begin{array}{l}40.0-85.0 \\
30.0-80.0\end{array}$ & $0.54 *$ \\
\hline & $\begin{array}{l}\text { P2 } \\
\text { P3 } \\
{ }_{2003-2004-1998} \\
\end{array}$ & $\begin{array}{l}270 \\
472\end{array}$ & $\begin{array}{l}50.0 \\
45.0\end{array}$ & $\begin{array}{l}40.0-80.0 \\
30.0-80.0\end{array}$ & $0.38^{*}$ \\
\hline \multirow{3}{*}{ Male } & $\begin{array}{l}\mathrm{P} 1_{1989-1992} \\
\mathrm{P} 2_{1996-1998}\end{array}$ & $\begin{array}{l}199 \\
141\end{array}$ & $\begin{array}{l}75.0 \\
55.0\end{array}$ & $\begin{array}{l}40.0-90.0 \\
45.0-90.0\end{array}$ & $0.31 *$ \\
\hline & $\begin{array}{l}\mathrm{P} 1_{1989-1992} \\
\mathrm{P} 3_{2003-2004}\end{array}$ & $\begin{array}{l}199 \\
114\end{array}$ & $\begin{array}{l}75.0 \\
65.0\end{array}$ & $\begin{array}{l}40.0-90.0 \\
35.0-80.0\end{array}$ & $0.38 *$ \\
\hline & $\begin{array}{l}\text { P2 } \\
\text { P3 }{ }_{2003-1998}\end{array}$ & $\begin{array}{l}141 \\
114\end{array}$ & $\begin{array}{l}55.0 \\
65.0\end{array}$ & $\begin{array}{l}45.0-90.0 \\
35.0-80.0\end{array}$ & $0.27 *$ \\
\hline
\end{tabular}

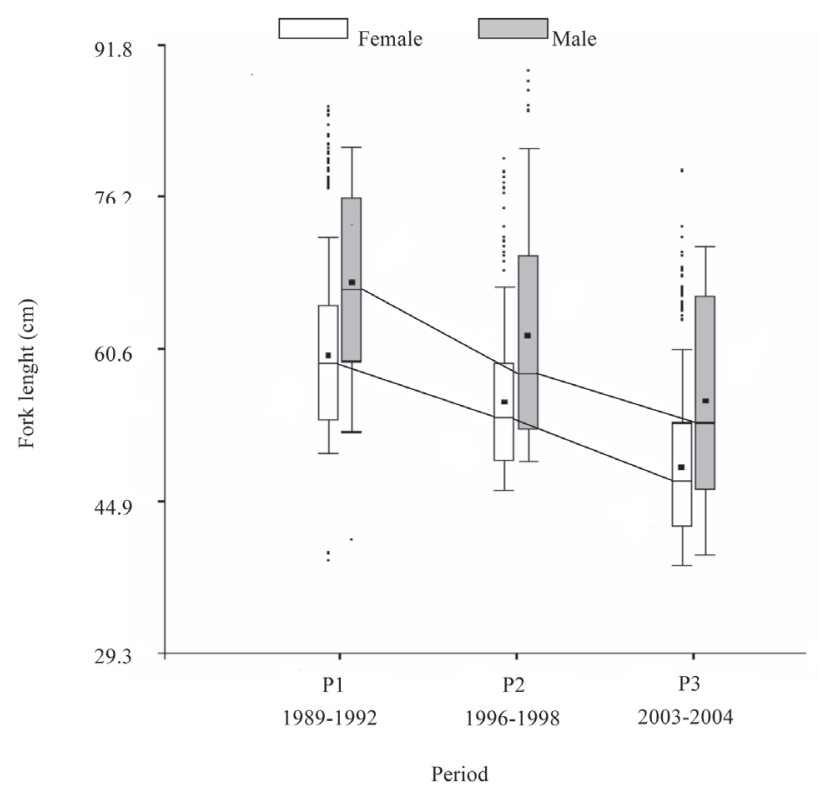

Fig. 2. Median size evolution of females and males red grouper from Campeche Bank collected during the three study periods, between 1989 and 2004. Within each box $50 \%$ of individuals analyzed are represented; points correspond to averages and lines medians

Fig. 2. Evolución de las medianas de talla de hembras y machos del mero rojo del Banco de Campeche colectadas durante los tres períodos de estudio, entre 1989-2004. Cada caja representa al 50\% de los individuos analizados, los puntos corresponden a los promedios y las líneas a las medianas 
Table 3. Comparisons of median size for female and male red grouper from Campeche Bank between the three study periods, during 1989-2004. df = degrees of freedom; $\mathrm{H}=$ Kruskall-Wallis test value; $* *=P<0.01$

Cuadro 3. Comparaciones de las medianas de talla para hembras y machos del mero rojo del Banco de Campeche entre tres períodos de estudio, durante 1989-2004. df = grados de libertad; $\mathrm{H}=$ valor de la prueba de Kruskall-Wallis; $* *=P<0.01$

\begin{tabular}{rlcccc}
\hline Sex & Period & N & $\begin{array}{c}\text { Median } \\
(\text { FL; cm) }\end{array}$ & df & H \\
\hline \multirow{3}{*}{ Female } & $\mathrm{P} 1_{1989-1992}$ & 676 & 59.0 & 2 & \\
& $\mathrm{P} 2^{1996-1998}$ & 270 & 53.5 & & $403.8^{* *}$ \\
& $\mathrm{P}{ }^{2003-2004}$ & 472 & 47.0 & 2 & \\
\multirow{3}{*}{ Male } & $\mathrm{P} 1_{1989-1992}$ & 199 & 66.6 & & $64.9^{* *}$ \\
& $\mathrm{P} 2^{1996-1998}$ & 141 & 58.0 & & \\
\hline
\end{tabular}

Table 4. Number of females and males; proportion of males and sex ratios observed during each study period for the red grouper from Campeche Bank between 1989 and 2004. $\mathrm{G}=\mathrm{G}$ replicated test value; $*=P<0.05$

Cuadro 4. Número de hembras y machos; proporción de machos observados durante cada período de estudio para el mero rojo del Banco de Campeche colectado durante 1989-2004. $\mathrm{G}=$ valor de la prueba $\mathrm{G}$ replicada; $*=P<0.05$

\begin{tabular}{|c|c|c|c|c|c|}
\hline \multirow{2}{*}{ Period } & \multirow{2}{*}{ Female } & \multicolumn{2}{|c|}{ Male } & \multirow{2}{*}{$\begin{array}{c}\text { Sex ratio } \\
\text { (male: female) }\end{array}$} & \multirow{2}{*}{$\mathbf{G}$} \\
\hline & & $\mathbf{N}$ & $\%$ & & \\
\hline $\mathrm{P} 1_{1989-1992}$ & 676 & 199 & 22.7 & $1: 3.4$ & $2197.3 *$ \\
\hline $\mathrm{P} 2_{1996-1998}$ & 270 & 141 & 34.3 & $1: 1.9$ & $944.2 *$ \\
\hline $\mathrm{P} 3_{2003-2004}$ & 472 & 114 & 19.4 & $1: 4.1$ & $1522.4 *$ \\
\hline
\end{tabular}

drastic decrease from the older to the most recent period was observed in the proportion of male present in the catches.

\section{Sizes at first sexual maturity and sex reversal}

Median sizes at first sexual maturity for females red grouper were calculated based on the size frequency distributions of immature and mature females presented in Fig. 3. These decreased progressively from the older to the most recent period: $59.0 \mathrm{~cm} \mathrm{FL}$ for $\mathrm{P}_{1989-1992} ; 53.5 \mathrm{~cm}$ for
P2 ${ }_{1996-1998}$ and $47 \mathrm{~cm} \mathrm{FL}$ for P3 ${ }_{2003-2004}$ and differed between periods (Kruskal-Wallis; Table 5).

Median sizes at sex reversal for females red grouper were calculated from the female and male size frequency distributions presented in Fig. 4. Size at sex reversal in females also tended to decrease progressively from the older to the most recent period: $60.5 \mathrm{~cm}$ for $\mathrm{P} 1_{1989}$ ${ }_{1992} ; 55.0 \mathrm{~cm}$ for $\mathrm{P} 2_{1996-1998}$ and $48.3 \mathrm{~cm}$ for $\mathrm{P} 3_{2003-2004}$ and differed between periods (Kruskal-Wallis; Table 5). 
Table 5. Comparisons of median sizes at first sexual maturity and at sex reversal for female red grouper from Campeche Bank between the three study periods, during 19892004. $\mathrm{df}=$ degrees of freedom; $\mathrm{H}=$ Kruskal-Wallis test value; $* *=P<0.01$

Cuadro 5. Comparación de las medianas de talla de primera madurez sexual y de inversión sexual para las hembras del mero rojo del Banco de Campeche entre los tres períodos de estudio, durante 1989-2004. df = grados de libertad; $\mathrm{H}=$ valor de la prueba de Kruskal-Wallis; $* *=P<0.01$

\begin{tabular}{|c|c|c|c|c|c|c|c|c|}
\hline \multirow[b]{2}{*}{ Period } & \multicolumn{4}{|c|}{ Size at 1 st maturity } & \multicolumn{4}{|c|}{ Size at sex reversal } \\
\hline & $\mathbf{N}$ & $\begin{array}{c}\text { Median } \\
\text { (FL; cm) }\end{array}$ & df & $\mathbf{H}$ & $\mathbf{n}$ & $\begin{array}{c}\text { Median } \\
\text { (FL; cm) }\end{array}$ & df & $\mathbf{H}$ \\
\hline $\mathrm{P} 1_{1}$ & 666 & 59.0 & & & 874 & 60.5 & & \\
\hline P2 & 270 & 53.5 & 2 & $410.2^{* *}$ & 389 & 55.0 & 2 & $445.6^{* *}$ \\
\hline $\mathrm{P} 3_{2003-2004}$ & 468 & 47.0 & & & 584 & 48.3 & & \\
\hline
\end{tabular}

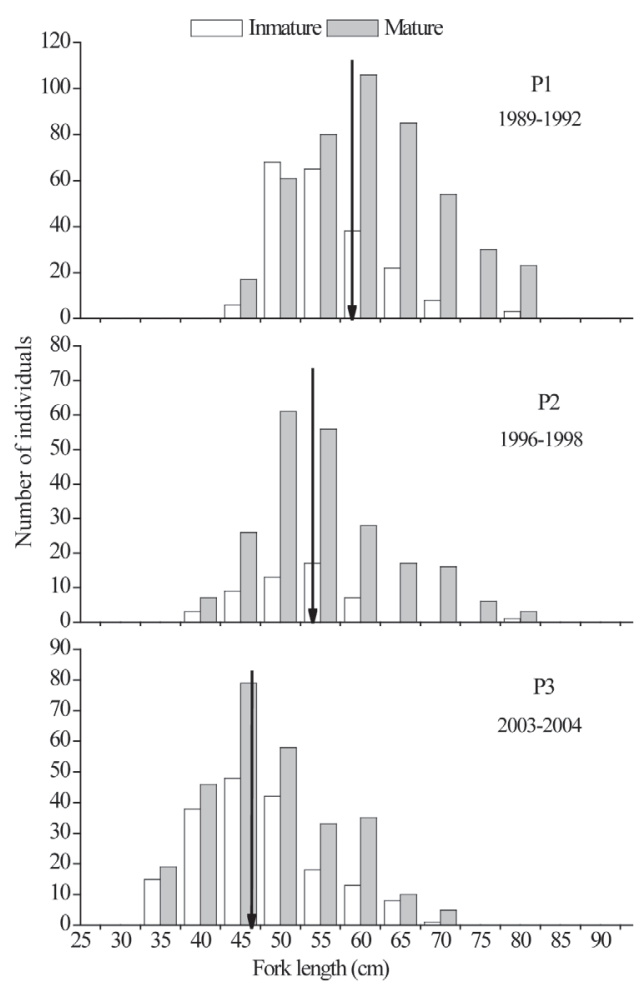

Fig. 3. Size frequency distributions for females red grouper from Campeche Bank, considering the size range within which mature and immature organisms occurred simultaneously for each study period, between 1989 and 2004. The black arrow indicates the median value as calculated from the distributions: $59.0 \mathrm{~cm} \mathrm{FL}$ for $\mathrm{P} 1_{1989-1992} ; 53.5 \mathrm{~cm} \mathrm{FL}$ for $\mathrm{P} 2_{1996-1998} ; 47.0 \mathrm{~cm} \mathrm{FL}$ for P $3_{2003-2004}$

Fig. 3. Distribuciones de frecuencia de tallas para las hembras del mero rojo del Banco de Campeche, considerando el rango donde ocurrieron las hembras maduras e inmaduras para cada período entre 1989 y 2004. La flecha negra indica el valor de la mediana calculada a partir de las distribuciones: $59.0 \mathrm{~cm}$ FL para $\mathrm{P} 1_{1989-1992} ; 53.5 \mathrm{~cm}$ FL para $\mathrm{P} 2_{1996-1998} ; 47.0 \mathrm{~cm}$ FL para $\mathrm{P} 3_{2003-2004}$ 


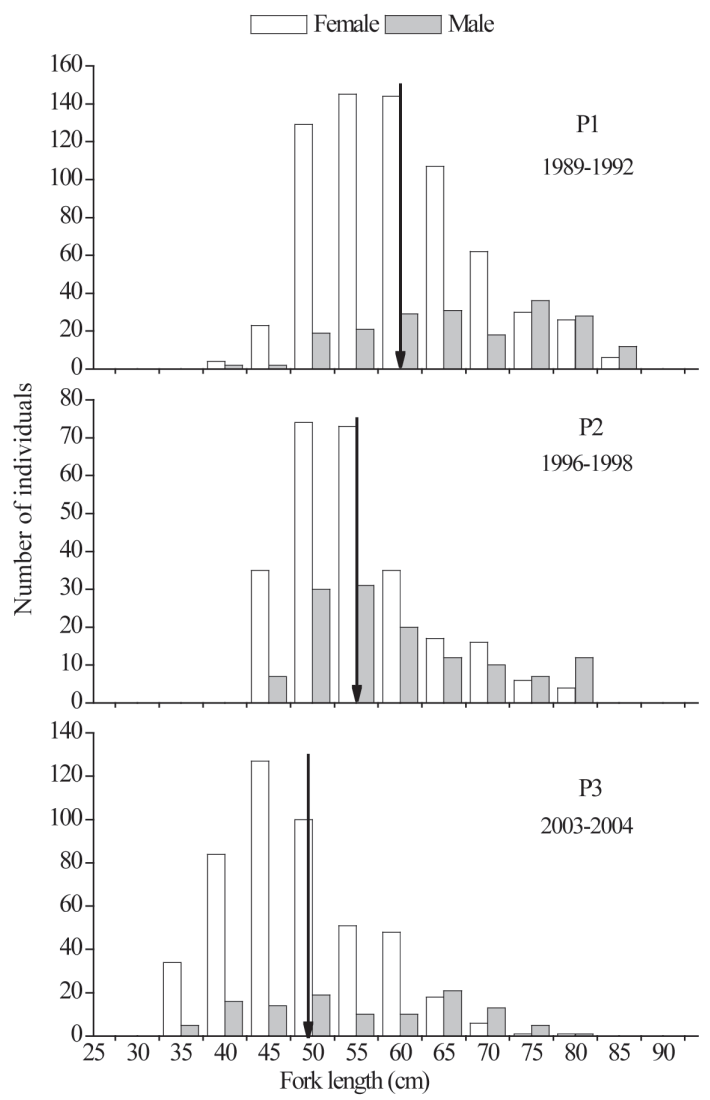

Fig. 4. Size frequency distributions for red grouper from Campeche Bank, considering the size range within which females and males occurred simultaneously for each study period, between 1989 and 2004. The black arrow indicates the median value as calculated from the distributions: $60.5 \mathrm{~cm} \mathrm{FL}$ for $\mathrm{P} 1_{1989-1992} ; 55.0 \mathrm{~cm}$ FL for $\mathrm{P} 2_{1996-1998} ; 48.3 \mathrm{~cm} \mathrm{FL}$ for $\mathrm{P} 3_{2003-2004}$

Fig. 4. Distribuciones de frecuencia de tallas del mero rojo del Banco de Campeche, considerando el rango de talla donde ocurrieron simultáneamente las hembras y los machos para cada período de estudio entre 1989-2004. La flecha negra indica el valor de la mediana calculado a partir de las distribuciones: $60.5 \mathrm{~cm}$ FL para P1 $1_{1989-1992} ; 55.0 \mathrm{~cm} \mathrm{FL} \mathrm{para} \mathrm{P} 2_{1996-1998} ; 48.3 \mathrm{~cm} \mathrm{FL}$ para P $3_{2003-2004}$

\section{DISCUSSION}

Size frequency distributions for females and males exhibited no change over time: males were always larger than females, independently of the period. Size difference by sex is often observed in fish species with successive protogynous hermaphroditism (Sadovy \& Shapiro, 1987), like red grouper (Valdés \& Padrón, 1980; Brulé et al. 1999; Burgos et al. 2007). This species is considered monandric (Brulé et al. 1999; Burgos et al. 2007), and males (called secondary) develop after an initial female stage and subsequent sex reversal (Reinboth, 1970; Sadovy \& Shapiro, 1987). Males are therefore largely absent in smaller size classes and 
dominate in the larger size classes (Levin \& Grimes, 2002).

Size frequency distributions for each sex and median sizes for females and males decreased over time. In a commercially-exploited fish stock, a decrease in the average size of organisms caught is an indicator of increased fishing pressure (King, 1995). Chiappone et al. (2000) state that intensive fishing pressure on grouper stocks causes diminished abundance, density and biomass, as well as a reduction in average size. For instance, Shapiro et al. (1993) reported decreases in average size of red hind Epinephelus guttatus in Puerto Rico due to fishing pressure. In a similar case, Coleman et al. (1996) observed changes in the demographics of the Gulf of Mexico gag population. These authors noted that, between 1980 and 1991-1993, the number of larger organisms and average size in females and males decreased in the northeastern Gulf of Mexico. McGovern et al. (1998) suggested that these demographic changes in the gag stock were the result of heavy fishing pressure in the years previous to the study.

The sex ratio was always biased towards females during all three periods. Based on the analysis of demographic structure by sex, this bias is coherent with this species' sexuality (Levin \& Grimes, 2002); red grouper is a protogynous hermaphroditic species and its populations contain a higher number of females than males (Valdés \& Padrón, 1980; Coleman et al. 1996; Brulé et al. 1999; Burgos et al. 2007). Although there were irregular variations in the number of males between periods, there was no trend towards a progressive or drastic decrease in the percentage of males over time. In protogynous hermaphroditic species, size selective catching of the largest individu- als is sex selective, and can lead to gradual reduction in the number of males in stock (Bannerot et al. 1987). For example the proportion of males in the gag stock decreased, from $17 \%$ during $1977-1980$ to $1 \%$ in 1991 in the north eastern Gulf of Mexico and from $17 \%$ before the 80 's to $3.4 \%$ in 1994 in the U.S. South Atlantic. The same occurred in the Gulf of Mexico scamp stock, where the percentage of males decreased from $36 \%$ in the late 1970 's to $18 \%$ in the early 1990 's (Coleman et al. 1996).

Both median sizes at which females could reach first sexual maturity and sex reversal decreased progressively from the older to the most recent period. Selective catch of larger females may lead surviving, smaller females to reach sexual maturity and, in the case of hermaphroditic species, cause them to reach sex reversal at an earlier age and smaller size (Vincent \& Sadovy, 1998). Coleman et al. (1996) reported a similar trend for gag in the north eastern Gulf of Mexico, where females reached first sexual maturity and began the sex reversal process at smaller sizes during 1991-1993 compared to 1977-1980 (Hood \& Schlieder, 1992). This was confirmed by McGovern et al. (1998) who reported that female gag matured at smaller sizes during 1994-1995 than during 1976-1982.

The reductions observed here in size of females and males, as well as in size at first maturity and sex reversal in females are probably the consequence of fishing intensity on the Campeche Bank red grouper stock. Notwithstanding, the Campeche Bank red grouper stock has maintained a relatively stable sex ratio, independent of the period analyzed. In addition, no drastic decline in the number of males was observed, contrary to what generally oc- 
curs when a protogynous species is caught selectively based on organism size. These results may be explained by the ethological characteristics of red grouper. Coleman et al. (1996) stated that a grouper species' reproductive behaviour can cause different responses to fishing impact. Although the grouper species studied to date generally exhibits the same pattern of sexuality (protogynous hermaphroditism), their reproductive behaviour differs markedly by species (Coleman et al. 1996; Levin \& Grimes, 2002). For example, gag and scamp migrate long distances to their spawning sites and form many, relatively small (10-100 individuals) and disperse aggregations (Coleman et al. 1996). Fishing on spawning aggregations means males could be more vulnerable than females. According to Gilmore \& Jones (1992), male gag and scamp remained relatively high in the water column during courtship behaviours and appeared to take baited hooks more aggressively than did females. Over time this kind of fishing can modify the demographic structure of stock in terms of size and age, as well as lead to the progressive and preferential disappearance of males. This process can produce a marked skewing of sex ratios in favour of females and consequently a progressive decrease in the proportion of males in the stock (Coleman et al. 2000). In contrast, males in species that do not form reproductive aggregations and which reproduces in small groups in extensive zones (e.g. red grouper) would be less vulnerable to the selective fishing effort focused on males. Under these conditions the sex ratio values and percentage of males would not experience significant temporal variations, independent of the fishing effort applied to the stock. The reduction in median size in females and males associated with the relative stability in the sex ratio of red grouper on Campeche Bank may also be explained by the determinism that controls sex change in hermaphroditic species. According to Vincent \& Sadovy (1998) sex change in these species may be influenced by both social (exogenous control) and genetic (endogenous control) factors, with variations in the dominance of one or the other according to species. Social factors offer the option of compensated sex change, that is, disappearance of males from a social group (for example, due to selective fishing) would be compensated for through sex reversal in an equivalent number of females (usually larger individuals) in the same group. In this case, group sex ratio would remain stable whereas both abundance and average size of females and males would tend to decrease as fishing continued. Genetic factors would induce uncompensated sex change at a fixed size or age with no influence from local changes in group social structure. In this case, sex ratio would tend to be more biased towards females, and abundance and average size would remain stable for females, but would decrease for males as selective fishing continued. The median size by sex and sex ratio results observed here imply that the studied red grouper stock may experience mostly compensated sex change under the influence of social factors. Finally, the sex reversal process in species with compensated sex change cannot occur without the presence of both sexes at the same time and place (Coleman et al. 1996). For some grouper species this time can be temporally limited within a year. For example, gag has a short reproduction period and both sexes are in the same sites only during spawning aggregations. The reproductive period of red grouper, by comparison, is longer, spawning does not occur in aggregations 
and both sexes inhabit the same habitats year round (Coleman et al. 1996). For red grouper, then, the sex change process is probably not restricted in time, which would allow this species to compensate for the loss of males caused by fishing, whenever this impact occurs. Therefore, Burgos et al. (2007) observed the occurrence of transitional red grouper individuals year round in the U.S. South Atlantic.

Red grouper is an important component of the grouper fishery off the U.S. South Atlantic coast, in the eastern and southern Gulf of Mexico and along the coast of Venezuela (Heemstra \& Randall, 1993). In the Gulf of Mexico, the Campeche Bank red grouper stock is probably more intensely fished than that of Florida. Indeed, Coleman et al. (1996) reported no notable change in organism size or sex ratio in the red grouper stock in the eastern Gulf of Mexico during the 25 to 30 years before their study, even though it is one of the most heavily exploited groupers in that region. The present results suggest that, despite its status as overfished and because of the red grouper reproductive strategy, the Campeche Bank red grouper stock may have a certain capacity for resilience in response to fishing pressure. The presence of compensated sex change could allow it to reduce the risks of a male deficit and any consequent scarcity of the sperm needed to fertilize oocytes. This is consistent with Coleman et al. (1996), who concluded that the response of shallow-water groupers to intense fishing pressure is directly related to their respective reproductive styles and that of the serranids red grouper is one of the least susceptible to local extinctions. Nonetheless, the risk of reproductive disruption may persist in species with compensated sex change, because mean female fecundity can decline as larger females are removed by selective extraction and sex change (Vincent \& Sadovy, 1998).

\section{ACKNOWLEDGMENTS}

This research was funded by an European Community (EC) grant No. C1*0432 ME (JR) and the Science and Technology Council of Mexico (CONACYT) grants 2184P-B9507 and 37606-B. For their assistance during this study, we would like to thank A. M. Pech de Quezada from CONYUC fish house; J. Rodríguez-Felix from S.S.S. "24 de febrero"; J. L. Carrillo-Galaz, F. Álvarez-Carrillo and C. Rubio-Díaz from the fishing cooperative "SCPP Federación Regional de Sociedades Cooperativas de la Industria Pesquera de la Zona Centro y Poniente del Estado de Yucatán". We are also grateful to T. Ramírez-Hernández, A. Tuz-Sulub and K. Cervera-Cervera and J. C. Espinoza-Méndez (CRIP Yucalpetén) for helping with all aspects of the field collections. We especially thank Silvia Salas from CINVESTAV-Unidad Mérida who reviewed and improved the manuscript.

\section{REFERENCES}

Alonzo, S. H. \& Mangel, M. (2004). The effects of size-selective fisheries on the stock dynamics of and sperm limitation in sex-changing fish. Fish. Bull., 102, 1-13.

Bannerot, S. P., Fox Jr., W. W. \& Powers, J. E. (1987). Reproductive strategies and the management of snappers and groupers in the Gulf on Mexico and Caribbean. En J. J. Polovina \& S. Ralston (Eds.), Tropical snappers and groupers: biology and fisheries management (pp. 561-603). Boulder, CO.: Westview Press.

Brulé, T., Déniel, C., Colás-Marrufo, T. \& Sánchez, M. (1999). Red grouper repro- 
duction in the southern Gulf of Mexico. Trans. Am. Fish. Soc., 128, 385-402.

Burgos, R. \& Defeo, O. (2004). Longterm population structure, mortality and modeling of a tropical multi-fleet fishery: the red grouper Epinephelus morio of the Campeche Bank, Gulf of Mexico. Fish. Res., 66, 325-335.

Burgos, J. M., Sedberry, G. R., Wyanski, D. M. \& Harris, P. J. (2007). Life history of red grouper (Epinephelus morio) off the coasts of North Carolina and South Carolina. Bull. Mar. Sci., 80, 45-65.

Chiappone, M., Sluka, R. \& Sullivan, K. M. (2000). Groupers (Pisces: Serranidae) in fished and protected areas of the Florida Keys, Bahamas and northern Caribbean. Mar. Ecol. Prog. Ser., 198, 261-272.

Coleman, F. C., Koenig, C. \& Collins, L. A. (1996). Reproductive styles of shallow-water groupers (Pisces: Serranidae) in the eastern Gulf of Mexico and the consequences of fishing spawning aggregations. Environ. Biol. Fishes., 47, 129-141.

Coleman, F. C., Koenig, C. C., Eklund, A. M. \& Grimes, C. B. (1999). Management and conservation of temperate reef fishes in the grouper-snapper complex of the southeastern United States. Am. Fish. Soc. Symp., 23, 233-242.

Coleman, F. C., Koenig, C. C., Huntsman, G. R., Musick, J. A., Eklund, A. M., McGovern, J. C., Chapman, R. W., Sedberry, G. R. \& Grimes, C. B. (2000). Long-lived reef fishes: the grouper-snapper complex. Fisheries, 25 (3), 14-21.

Gabe, M. (1968). Techniques histologiques. Paris: Masson and Cie.

Gilmore, R. G. \& Jones, R. S. (1992). Color variation and associated behavior in the epinepheline groupers, Mycteroperca microlepis (Goode and Bean) and M. phenax Jordan and Swain. Bull. Mar. Sci., 51, 83-103.

Giménez-Hurtado, E., Coyula-PérezPuelles, R., Lluch-Cota, S. E., González-Yáñez, A. A., MorenoGarcía, V. \& Burgo, R. (2005). Historical biomass, fishing mortality, and recruitment trends of the Campeche Bank red grouper (Epinephelus morio). Fish. Res., 71, 267-277.

Heemstra, P. C. \& Randall, J. E. (1993). FAO species catalogue. Vol. 16. Groupers of the world (family Serranidae, subfamily Epinephelinae). An annotated and illustrated catalogue of the grouper, rockcod, hind, coral grouper and lyretail species known to date. Roma, Italia: FAO. Fisheries Synopsis.

Hood, P. B. \& Schlieder, R. A. (1992). Age, growth and reproduction of gag Mycteroperca microlepis (Pisces: Serranidae), in the Eastern Gulf of Mexico. Bull. Mar. Sci., 51, 337-352.

Kartas, F. \& Quignard, J. P. (1984). La fécondité des poissons Téléostéens. Paris: Masson and Cie.

King, M. (1995). Fisheries biology, assessment and management. Oxford, EE. UU.: Fishing News Books, Blackwell Science.

Levin, P. S. \& Grimes, C. B. (2002). Reef fish ecology and grouper conservation and management. En P. F. Sale (Ed.), Coral reeffishes: dynamics and diversity in a complex ecosystem (pp. 377-389). Amsterdam, Holland: Academic Press.

McGovern, J. C., Wyanski, D. M., Pashuk, O., Manooch II, C. S. \& Sedberry, G. S. (1998). Changes in the sex ratio and size at maturity of gag Mycteroperca microlepis from the Atlantic coast of 
the southeastern United States during 1976-1995. Fish. Bull, 96, 797-807.

Morris, A. V., Callum, M. R. \& Hawkins, J. P. (2000). The threatened status of groupers (Epinephelinae). Biodivers Conserv., 9, 919-942.

Ralston, S. (1987). Mortality rates of snappers and groupers. En J. J. Polovina \& S. Ralston (Eds.), Tropical snappers and groupers: biology and fisheries management (pp. 375-404). Boulder, CO.: Westview Press.

Reinboth, R. (1970). Intersexuality in fishes. Mem. Soc. Endocrinol., 18, 515-543.

Rhodes, K. L. \& Sadovy, Y. (2002). Reproduction in the camouflage grouper (Pisces: Serranidae) in Pohnpei, Federate States of Micronesia. Bull. Mar. Sci., 70, 851-869.

Sadovy, Y. (1996). Reproduction of reef fishery species. En N. V. C. Polunin \& C. M. Roberts (Eds.), Reef fisheries (pp. 15-59). London: Chapman and Hall.

Sadovy, Y. \& Shapiro, D. Y. (1987). Criteria of diagnosis of hermafroditism in fishes. Copeia., 1, 136-156.

SAGARPA (Secretaría de Agricultura, Ganadería, Desarrollo Rural, Pesca y Alimentación). (2005). Anuario estadístico de pesca 2003. México, D.F.: CONAPESCA, SAGARPA.

SAGARPA (Secretaría de Agricultura, Ganadería, Desarrollo Rural, Pesca y Alimentación). (2006). Carta nacional pesquera. En A. López González (Ed.), Diario Oficial de la Federación, Tomo DCXXXV 19 (2da. sección) (pp.
1-128). México, D.F.: CONAPESCA, SAGARPA.

Shapiro, D. Y. (1984). Sex reversal and sociodemographic process in coral reef fishes. En G. W. Potts \& R. J. Wootton (Eds.), Fish reproduction: strategies and tactics (pp. 103-118). London: Academic Press.

Shapiro, D. Y., Sadovy, Y. \& McGehee, M. A. (1993). Size, composition and special structure of annual spawning aggregation of the red hind, Epinephelus guttatus (Pisces: Serranidae). Copeia., 2, 399-406.

Smith, C. L. (1959). Hermaphroditism in some serranid fishes from Bermuda. Pap. Mich. Acad. Sci., 44, 111-119.

Sokal, R. R. \& Rohlf, F. J. (1997). Biometry: the principles and practice of statistics in biological research. New York: W. H. Freeman \& Co.

Valdés, E. \& Padrón, G. (1980). Pesquerías de palangre. Rev. Cub. Inv. Pesq., 5, 38-52.

Vincent, A. \& Sadovy, Y. (1998). Reproductive ecology in the conservation and management of fishes. In T. Caro (Ed.), Behavioral ecology and conservation biology (pp. 209-245). New York, EE. UU.: Oxford University Press.

Wallace, R. A. \& Selman, K. (1981). Cellular and dynamic aspects of oocyte growth in teleost. Amer. Zool., 21, 325343. 